This is an electronic reprint of the original article. This reprint may differ from the original in pagination and typographic detail.

Author(s): Tokila, Anu; Haapanen, Mika

Title: $\quad$ Evaluating project deadweight measures: evidence from Finnish business subsidies

Year: $\quad 2009$

Version:

Please cite the original version:

Tokila, A., \& Haapanen, M. (2009). Evaluating project deadweight measures:

evidence from Finnish business subsidies. Environment and Planning C: Government and Policy, 27(1), 124-140. https://doi.org/10.1068/c0804b

All material supplied via JYX is protected by copyright and other intellectual property rights, and duplication or sale of all or part of any of the repository collections is not permitted, except that material may be duplicated by you for your research use or educational purposes in electronic or print form. You must obtain permission for any other use. Electronic or print copies may not be offered, whether for sale or otherwise to anyone who is not an authorised user. 


\title{
Evaluating project deadweight measures: evidence from Finnish business subsidies
}

\author{
Anu Tokila and Mika Haapanen* \\ School of Business and Economics, University of Jyväskylä
}

14 May 2008

\begin{abstract}
An important problem in measuring the impacts of business subsidies is their separation from deadweight, which refers to changes that would have occurred even in the absence of intervention. Both public and private assessments have been used previously to study deadweight, but so far little is known about how they correspond to each other. To address this issue, we conducted a joint evaluation of the private and public assessments of deadweight for Finnish business projects. A unique data set combines large register data with both public and private information on projects financed in 2000-2003. First, our results suggest that the different measures for deadweight are greatly uncorrelated, and thus cannot be used as substitutes. Second, characteristics affecting the public and private measures of deadweight are identified using ordered probit models. We find that the public and private sectors emphasize different factors in their assessment of deadweight. Third, an upper bound for the level of deadweight spending is estimated at $73.8 \%$.
\end{abstract}

\footnotetext{
* Contact information: School of Business and Economics, P.O. Box 35, FIN-40014 University of Jyväskylä, Finland. Emails: anu.tokila@econ.jyu.fi and mika.haapanen@econ.jyu.fi. The paper is a part of a Research Programme on Business Know-how (LIIKE2, project no 112116) financed by the Academy of Finland. The financial support from the Yrjö Jahnsson Foundation (project 5597) is gratefully acknowledged by the first author. The authors are also grateful for the helpful comments provided by Hannu Tervo, Ari Hyytinen and two anonymous referees on an earlier draft of this paper.
} 


\section{Introduction}

Governments all over the world use business subsidies to maximize social and economic welfare. Entrepreneurs are believed to generate positive outcomes such as new innovations and employment, which in turn motivate the use of public interventions in the absence of private investment (Parker, 2004). Access to private equity and loans can prove an obstacle, even for firms with a profitable project, if the market does not correctly or fully value the social benefits resulting from entrepreneurship. This situation indicates market failure, which frequently results in misallocation of resources (Glancey, 2000).

Different theoretical reasons have been suggested for the existence of market failures ${ }^{1}$. In practice, the latest studies suggest that information imperfections and indirect positive externalities could be the main reasons for the market failures identified in the financial market of SMEs (eg European Commission, 2007; Stam et al, 2007). With regard to information imperfections ${ }^{2}$, financial institutions may not be able to recognize viable and potential projects; this can lead to overestimated risk rates and rejection of financing (eg Stiglitz and Weiss, 1981). Such imperfections may result from shortcomings in the bank's assessment process, or from too negative expectations on behalf of the applicant firm (Stam et al, 2007). When the participants are not equally well-informed, the market outcome might not prove efficient without public intervention (Leach, 2003). This happens if socially viable projects are not implemented in the absence of finance. Governments can fill the information gap either through full

\footnotetext{
${ }^{1}$ Much-referred Stiglitz (1988) specifies six main reasons for market failure existence, namely, failure of information, existence of public goods, incomplete markets, externalities, failure of competition, and macroeconomic disequilibrium.

${ }^{2}$ In such case, information may be missing, inadequate, or incorrect (Glancey, 2000).
} 
or partial finance, which provides information on a project's viability to private financiers.

Externality refers to the divergence of private and social costs (Glancey, 2000). An externality is positive if the behavior of some agent makes another agent better, and is negative if that behavior makes another agent worse. In a situation with positive externalities, the social returns of a business project exceed its private returns. These economic benefits may not be fully incorporated into the market. Research and development (R\&D) activity provides a good example of such a situation. R\&D commonly yields external positive impacts - such as technological spillovers - that benefit society as a whole more than a firm itself. Without public support, the level of R\&D activity may not be sufficient for society (Bartik, 1990).

The task of correcting market failures generally falls on the government (Leach, 2003). For example, the intervention logic underpinning European Union support for small and medium-sized enterprises stems much from the presence of market failure and market gaps (European Commission, 2007). However, market failures do not necessarily justify government intervention; interventions must also be beneficial and lead to improved resource allocation. In other words, subsidies among other government interventions should lead to a Pareto-optimal allocation of resources. In practice, government is represented by an individual who is supposed to possess all the relevant information to determine the Pareto-optimal allocation of resources, on the basis of which the decision on optimal subsidies is made (Mueller, 2003). In that optimal situation, economic intervention is supposed to increase social welfare.

However, inefficiency may arise for different reasons. Public subsidies may encourage the firm to reduce its inputs to the project. In the worst case, subsidy entirely substitutes private funds and does not generate an increase in the scale of the project, and thus 
implies an arbitrary transfer of resources from tax payer to producer (Wren, 1996). In that event, the firm may have obtained finance from other sources; therefore public resources are being used unnecessarily. This leads us to the problem of deadweight discussed in this paper. More precisely, we focus on project deadweight, in which deadweight is defined as the degree or level to which a project would have been carried out without grant assistance (see Lenihan, 1999; 2004). ${ }^{3}$

Deadweight represents a situation in which private benefits are increased at the expense of social welfare. Hence, public and private benefits are highly divergent in terms of deadweight. For this reason, assessments of deadweight cannot be expected to be similar between those groups. Previous studies have been based solely on either private (eg Lenihan, 1999; 2004) or public (Tokila et al, 2008) assessment of deadweight: a comparative study of deadweight assessments by the public sector and by the private firm itself is lacking. Our study aims to fill this gap in literature. We analyze and discuss the correlation between different measures of project deadweight. ${ }^{4}$ Then we identify the characteristics that affect deadweight measures. Comparison of these characteristics can indicate differences in the processes that generate the private and public measures of deadweight. Lastly, we calculate estimates for deadweight spending. Thus, we offer an extensive analysis of project deadweight, and broaden information on the analytical methods for studying deadweight.

\footnotetext{
${ }^{3}$ The concept of deadweight with this meaning has been known from the 1980s (see, for instance, Robinson et al, 1987), but Lenihan has brought back the concept into the literature. Related topics have been evaluated even earlier (see eg Zimmermann, 1985). This concept of deadweight should not be confused with the concept of deadweight loss, which can be defined as a loss in economic efficiency in the market caused by, for example, taxation, monopoly power, and the price ceiling or floor (see eg Frank and Bernanke, 2001; Hines, 1999).

${ }^{4}$ To evaluate the reliability of the private deadweight assessment, an alternative indirect measure of deadweight based on the grant replacement possibilities is also used.
} 


\section{Literature on deadweight}

In terms of public subsidies, deadweight is recognized as a counterfactual component of additionality $^{5}$. At project level, deadweight can be directly identified as a nonadditionality (see eg Luukkonen, 2000), but at a regional level, displacement ${ }^{6}$ and other possible replacement effects must also be taken into account. Additionality measures the net sum of the direct and indirect impacts generated due to intervention, whereas possible deadweight and displacement tend to reduce them. However, the percentage level of deadweight involved in each project is difficult to assess. Lenihan (1999) draws a distinction between full (pure), partial, and zero deadweight. The former refers to a situation in which the project would have been implemented unchanged without a grant subsidy. Thus, the level of deadweight is $100 \%$. In the opposite situation, the project would have been abandoned without receiving subsidy. Then, deadweight does not occur; that is, there is zero deadweight. Partial deadweight lies somewhere between full and zero deadweight. It can occur, for instance, when a project would have gone ahead on a reduced scale or quality, or with a delayed time schedule, if a subsidy was not granted (cf. Lenihan, 1999, 2004; Lenihan and Hart, 2004).

Project deadweight is a young and widely unexplored academic field. Lenihan (1999, 2004) has done pioneer work of deadweight with Irish data (see also Lenihan and Hart, 2004; Lenihan et al, 2005). Her results indicate that deadweight is a problem to be reckoned with. Estimates of deadweight levels are high according to different ways of calculation. Deadweight can constitute up to $78 \%$ of employment and $56 \%$ of the share

\footnotetext{
${ }^{5}$ Additionality is a concept used with several meanings in the subsidy literature. Besides project additionality, output additionality, and input additionality, behavioural additionality and cognitive capacity additionality are also known (see Davenport et al, 1998; Georghiou et al, 2002).

${ }^{6}$ Displacement occurs if the subsidized project causes activity reduction elsewhere in the economy. Consideration of displacement is essential when evaluating regional net impacts of the policies (see eg Tervo, 1989; 1990).
} 
of assistance approved, and can occur in more than $90 \%$ of subsidized business projects (Lenihan, 1999; Lenihan and Hart, 2004).

Prior evidence of the reasons behind deadweight is equally limited thus far. Some evidence of the determinants of deadweight has been reported separately on a public and private basis. In Lenihan's (2004) analysis, the level of deadweight was found to be influenced by grant type, size of firm, number of earlier grants, and whether the investment appraisal included a grant. In that study, data were collected via interviews from the firms. Tokila et al (2008) utilized register data to analyze conditions for zero deadweight. Here, the deadweight of a project was evaluated by public researchers. Analysis showed that a location in a prosperous region, a strong investment-bearing capacity, a higher age of firm, and a large subsidy size may raise the likelihood of deadweight when considering investment projects.

Analyses of project additionality offer an indirect view into deadweight. Many of this type of studies indicate that public subsidies do not have a significant effect on the implementation of a project, which strongly suggests occurrence of deadweight (see eg Luukkonen, 2000). These studies show that larger firms, firms with higher activity in $\mathrm{R} \& \mathrm{D}$, and firms with more expensive projects are more likely to carry on the same level of activities even in the absence of support (eg Heijs, 2003). These studies are typically based on surveys or interviews, and therefore offer a private assessment of the subject. However, project additionality should not be confused with the large literature of input additionality, in which the concept of additionality is somewhat different (see eg Czarnitzki and Fier, 2002; David et al, 2000; González et al, 2005; Kaiser, 2004; Lach, 2002; Wallsten, 2000). These focus on how public support influences a project's private finance: a common viewpoint, especially within R\&D subsidies. 


\section{Business subsidies in Finland}

Although the share of business subsidies from government expenditure is smaller in Finland compared to other EU-15 member states, the amount spent on those subsidies is still significant (see Venetoklis, 2001). The Ministry of Trade and Industry (KTM) ${ }^{7}$, the major distributor of aid to businesses, makes over fifty percent of all subsidy appropriations. Although KTM participates in business venturing by many instruments such as loans and guarantees, the subsidies we are concerned with are all grants; that is, the recipient firm is not obliged to pay back the grant to the distributor. In 2000-2003, three types of subsidies for implementation of business projects were available, subsidies for investment, development, and operating environment projects. The latter subsidies differ from the others because they are not granted directly to firms, but to projects initiated mostly by foundations or by public or private-sector corporations, in order to improve the business environment of companies. Therefore, such projects are not comparable in deadweight with other projects, and are excluded from this analysis. The other two forms of aid are granted directly to micro, small, and medium-sized enterprises ${ }^{8}$. Only in rare cases are subsidies granted to larger enterprises.

Investments subsidies can be granted to a firm for fixed-asset investment projects when a firm is starting its business, expanding operations, or modernizing its fixed assets. Development subsidies can be granted to projects enhancing the competitiveness or internationalization of an enterprise in the long term (Aid to Business Act, 2000). Intensity of assistance is dependent on the type of assisted area, size of the firm, and the

\footnotetext{
${ }^{7}$ However, the system for business subsidies is very fragmented. Public finance for enterprises is also granted by the ministries of Foreign Affairs, Transport and Communications, Labour, Agriculture and Forestry and Finance (Muotio, 1998).
} 
form of subsidy. For development projects, the intensity of assistance is generally higher, reaching up to $50 \%$ of accepted costs. With regard to investment projects, small firms may be granted $10-30 \%$ of the costs, and medium-sized firms $5-20 \%$ of the costs (Decree of Council of State, 2000).

For example, in 2003 , KTM granted a total of $€ 107$ million business subsidies. In total, of the 3405 projects that applied for financing, 893 were denied subsidy ${ }^{9}$ (Ministry of Trade and Industry, 2004). Subsidies were mostly granted to micro and small-sized firms. With regard to the project type, the share of investment projects was larger compared to that of development projects, in terms of both number of projects and their financing. Financing for investment projects was more than twice that of development projects.

In practice, subsidies are applied for from the fifteen local Employment and Economic Development Centres, where they are also mostly granted. The Ministry of Trade and Industry only makes financing decisions in cases where the cost of the investment project exceeds $€ 1.7$ million. To receive subsidies, feasible project and financing plans are required, and an assessment made by the researchers at the Employment and Economic Development Centre. In the assessment process, the project, the applicant firm, and the need for public finance are fully described and evaluated. In addition, predictions of the financial situation of the firm and of the financial impact of the project must be favorable.

\footnotetext{
${ }^{8}$ A micro-sized (small-sized, medium-sized) enterprise refers to enterprise which employs fewer than $10(50,250)$ persons, has an annual turnover not exceeding $€ 2(10,50)$ million or an annual balance sheet total not exceeding $€ 2(10,43)$ million, and fulfils the characteristics depicting the autonomy of an enterprise (European Commission, 2003/361/EC).

${ }^{9}$ Unfortunately, no information is recorded on the rejected projects.
} 


\section{Data and deadweight measures}

In the empirical analysis, we investigate deadweight in the business projects for which the Ministry of Trade and Industry granted subsidies between 2000 and 2003. We use a unique data set from two sources; first, register data comprising all the financed projects (5 844 projects), of which 5744 were conducted by private sector firms. These private sector projects were selected for analysis. The data set is considerably larger than that of most previous deadweight studies (see reviews by Foley, 1992, and Lenihan et al, 2004), and includes a broad range of information on the firms and their projects (see Appendix, Table A1). ${ }^{10}$

Importantly, the register data set in this study contains information on the public assessment of deadweight for all the financed projects. In the assessment, the project and the firm are evaluated by the researchers at the Employment and Economic Development Centre. The researchers raise a hypothetical counterfactual question: what would happen if the project were not subsidized? The options that answer this question are as follows: (1) the project will be abandoned; (2) the project will be implemented on a reduced scale; (3) the project will be implemented on a reduced qualitative level; (4) the project will be implemented at a later date; and (5) the project will be implemented unchanged. Hence, option (1) implies zero deadweight, options (2)-(4) imply partial degrees of deadweight, and option (5) implies pure deadweight.

Second, to gather private information on deadweight, 222 firms were interviewed at the end of 2004; that is, one to three years after the beginning of their projects. The sample

${ }^{10}$ The register data set is used to form our explanatory variables of econometric model introduced later. 
was randomly selected from the population of subsidized private projects. ${ }^{11}$ The telephone interviews, lasting an average of 30 minutes, were carried out by structured questionnaire ${ }^{12}$ sent to the respondents in advance. The respondents were firm-owners or project managers: whoever was most involved with the implementation of the subsidized project. Project deadweight was assessed through the same counterfactual question mentioned earlier.

It must be assumed that a firm knows the 'real' deadweight, what would really happen if a project was not subsidized. While making an assessment, the firm attends to factors that affect project implementation. The researcher ought to assess this real deadweight by certain criteria; however, the researcher may not have the full information about the firm due to asymmetric information, or the criteria may emphasize different factors than the firm emphasizes in its assessment. Furthermore, both assessments may be influenced by subjective motives, which may constitute interpretation of possible differences in the results. The researcher's assessment of deadweight may be influenced by a "pick-the-winners" effect. This means that authorities may favor those projects with the most potential, projects which could have been implemented unchanged without subsidy, as successful projects improve the records of the researcher and ensure performance pay. Self-assessment of deadweight may be problematic due to 'respondent's effect' or 'response bias' (Lenihan, 1999; Lenihan and Hart, 2004; McEldowney, 1997), which means that respondents may purposely underestimate or overestimate the impact of financing. Some might be over-optimistic, as a positive outlook is likely to be a common characteristic of entrepreneurs. Others might be pessimistic, thinking their response would help gain future support (Curran and Storey,

\footnotetext{
${ }^{11}$ Representativeness of the sample was investigated using distribution tests. They showed that the sample is identical to the population in most characteristics. The test results are available on request from the authors.
} 
2000). As regards deadweight, underestimation of the changes that would have occurred in the absence of intervention is the most likely case (European Commission, 2006).

To investigate the reliability of the deadweight assessments, an alternative indirect measure of project deadweight is used, a measure that can be drawn from subsidy replacement possibilities. In the interview, firms were also asked whether the subsidy could have been replaced by another funding method. Replying 'yes, completely' can be seen as an indication of full deadweight. Partial replacement possibilities indicate partial deadweight and 'no possibility' zero deadweight.

Table 1 shows the frequency distributions of the deadweight measures. The distribution of the public assessment is similar between population and sample (columns 1a and 1b). Partial deadweight dominates, while the number of full deadweight projects is low. The distribution of private assessment shows a higher degree of zero deadweight as well as a higher degree of full deadweight (column 2). When the deadweight is investigated indirectly, by asking about the firm's subsidy replacement possibilities (column 3), distribution is much more constant than that of a direct assessment of deadweight. While the distributions depend somewhat on the measure used in calculation of deadweight, these simple figures indicate some form of deadweight in $66-84 \%$ of the subsidized projects. The range is in line with prior evidence. For example, Lenihan (1999) found deadweight in $90 \%$ of business projects when firms were asked directly. The first estimates from Robinson et al (1987) were somewhat lower, namely, 38.4 to 73.9\%. In our sample data, the largest deadweight estimate is from the public assessment (84\%), and the smallest from the indirect private assessment (66\%), with the direct private assessment of deadweight (79\%) between the two. A comparison of the

\footnotetext{
${ }^{12}$ The questionnaire was tested with ten firms to ensure that questions are clear and that there is no confusion regarding the issues addressed.
} 
private deadweight figures indicates that direct assessment may underestimate both full and zero deadweight. Thus, no direct conclusion from the overall difference can be drawn.

Table 1. Frequency distributions of alternative deadweight measures

\begin{tabular}{|c|c|c|c|c|c|c|c|c|}
\hline \multirow{2}{*}{$\begin{array}{l}\text { Dead- } \\
\text { weight }\end{array}$} & \multicolumn{2}{|c|}{$\begin{array}{c}\text { 1a) DW } \\
\text { assessment by } \\
\text { researchers } \\
\text { (population) }\end{array}$} & \multicolumn{2}{|c|}{$\begin{array}{l}\text { 1b) DW } \\
\text { assessment by } \\
\text { researchers } \\
\text { (sample) }\end{array}$} & \multicolumn{2}{|c|}{$\begin{array}{c}\text { 2) DW } \\
\text { assessment by } \\
\text { firms }\end{array}$} & \multicolumn{2}{|c|}{$\begin{array}{l}\text { 3) Subsidy } \\
\text { replacement } \\
\text { possibilities as } \\
\text { reported by firms }\end{array}$} \\
\hline & 967 & $(16.8 \%)$ & 36 & $(16.2 \%)$ & 47 & $(21.3 \%)$ & 75 & $(33.8 \%)$ \\
\hline Partial & 4695 & $(81.7 \%)$ & 183 & $(82.4 \%)$ & 149 & $(67.4 \%)$ & 79 & $(35.6 \%)$ \\
\hline Full & 82 & $(1.4 \%)$ & 3 & $(1.4 \%)$ & 25 & $(11.3 \%)$ & 68 & $(30.6 \%)$ \\
\hline Total & 5744 & $(100 \%)$ & 222 & $(100 \%)$ & 221 & $(100 \%)$ & 222 & $(100 \%)$ \\
\hline
\end{tabular}

\section{Correlation between deadweight measures}

These simple frequency distributions do not, however, reveal whether the deadweight of a particular project is evaluated similarly by public sector and firm. The direction and strength of the pair-wise relationship between public and private measures can be investigated using Kendall's $\tau_{b}$ coefficient (Agresti, 1984; Kendall and Gibbons, 1990). This nonparametric coefficient of association for ordinal variables can have values between -1 and 1 . The sign of the coefficient indicates the direction of the relationship, and its absolute value the strength of the relationship. The coefficient reaches 1 when all entries are on the diagonal of a square bivariate frequency table.

Positive but not necessarily significant relationships are expected between the alternative measures of deadweight. As discussed, besides the pick-winners-effect and response bias, asymmetric information may produce differences in the measures. Many essential features of the project and its funding possibilities are known only to the firm. Therefore, public assessment may not be able to recognize the real deadweight of a project. A public researcher may also intentionally stress firm, project, and regional 
factors differently than a private firm. The researcher may, for example, emphasize local unemployment when considering the necessity of finance and level of deadweight.

Table 2 presents the cross-tabulation of deadweight measures and their pair-wise correlation coefficients. Sample data the 222 subsidized projects are used. Although the correlation between the public and private assessment of deadweight ( $1 \mathrm{~b}$ and 2 ) is significantly different from zero $(p<0.01)$ and positive, the relationship is rather weak (Kendall's $\tau_{b}=0.172$ ). This can be seen also in the sample frequencies. For example, of those 36 projects that public researchers label zero deadweight projects, some form of deadweight is reported in more than half of the private assessments. No significant relationship between the public assessment of deadweight and the indirect measurement of private deadweight ( $1 \mathrm{~b}$ and 3 ) is found. The correlation coefficient is practically zero $\left(\tau_{b}=0.009\right)$ and highly insignificant $(p=0.887)$. The strongest, but again fairly moderate, relationship is found between the two private measures of deadweight $\left(\tau_{b}=\right.$ 0.276). The null hypothesis of independence is clearly rejected $(p<0.001)$. 
Table 2. Cross-tabulation of deadweight measures: observed and expected frequencies

\begin{tabular}{|c|c|c|c|c|c|c|c|c|}
\hline \multirow{2}{*}{$\begin{array}{l}\text { 1b) Deadweight } \\
\text { assessment by } \\
\text { researchers } \\
\text { (sample) }\end{array}$} & \multicolumn{4}{|c|}{$\begin{array}{l}\text { 2) Deadweight assessment } \\
\text { by firms }\end{array}$} & \multicolumn{4}{|c|}{$\begin{array}{l}\text { 3) Subsidy replacement possibilities } \\
\text { as reported by firms }\end{array}$} \\
\hline & Zero & Partial & Full & Total & Zero & Partial & Full & Total \\
\hline Zero & $\begin{array}{c}13 \\
(7.7)\end{array}$ & $\begin{array}{c}21 \\
(24.3)\end{array}$ & $\begin{array}{c}2 \\
(4.1)\end{array}$ & 36 & $\begin{array}{c}12 \\
(12.2)\end{array}$ & $\begin{array}{c}12 \\
(12.8)\end{array}$ & $\begin{array}{c}12 \\
(11)\end{array}$ & 36 \\
\hline Partial & $\begin{array}{c}34 \\
(38.7)\end{array}$ & $\begin{array}{c}126 \\
(123)\end{array}$ & $\begin{array}{c}22 \\
(20.6)\end{array}$ & 182 & $\begin{array}{c}63 \\
(61.8)\end{array}$ & $\begin{array}{c}66 \\
(65.1)\end{array}$ & $\begin{array}{c}54 \\
(56.1)\end{array}$ & 183 \\
\hline Full & $\begin{array}{c}0 \\
(0.6)\end{array}$ & $\begin{array}{c}2 \\
(2)\end{array}$ & $\begin{array}{c}1 \\
(0.3)\end{array}$ & 3 & $\begin{array}{c}0 \\
(1)\end{array}$ & $\begin{array}{c}1 \\
(1.1)\end{array}$ & $\begin{array}{c}2 \\
(0.9)\end{array}$ & 3 \\
\hline Total & 47 & 149 & 25 & 221 & 75 & 79 & 68 & 222 \\
\hline \multirow{2}{*}{$\begin{array}{l}\text { 2) Deadweight } \\
\text { assessment by } \\
\text { firms }\end{array}$} & \multicolumn{4}{|c|}{$\begin{array}{l}\text { 3) Subsidy replacement possibilities } \\
\text { as reported by firms }\end{array}$} & \multirow{2}{*}{\multicolumn{4}{|c|}{ Coefficients of association }} \\
\hline & Zero & Partial & Full & Total & & & & \\
\hline Zero & $\begin{array}{l}29 \\
(16)\end{array}$ & $\begin{array}{c}15 \\
(16.8)\end{array}$ & $\begin{array}{c}3 \\
(14.2)\end{array}$ & 47 & \multirow{4}{*}{\multicolumn{4}{|c|}{$\begin{array}{c}\text { 1b vs. } 2: \tau_{b}=0.172 \\
\text { (Test of independence: } p=0.008 \text { ) } \\
\text { 1b vs. 3: } \tau_{b}=0.009 \\
\text { (Test of independence: } p=0.887 \text { ) } \\
2 \text { vs. 3: } \tau_{b}=0.276 \\
\text { (Test of independence: } p<0.001 \text { ) }\end{array}$}} \\
\hline Partial & $\begin{array}{c}39 \\
(50.6)\end{array}$ & $\begin{array}{c}57 \\
(53.3)\end{array}$ & $\begin{array}{c}53 \\
(45.2)\end{array}$ & 149 & & & & \\
\hline Full & $\begin{array}{c}7 \\
(8.5) \\
\end{array}$ & $\begin{array}{c}7 \\
(8.9) \\
\end{array}$ & $\begin{array}{c}11 \\
(7.6)\end{array}$ & 25 & & & & \\
\hline Total & 75 & 79 & 67 & 221 & & & & \\
\hline
\end{tabular}

These results show that public and private views differ on the deadweight of the project.

They constitute different measures for deadweight and cannot be used as substitutes.

Since the firms report more of both zero and full deadweight, no clear explanation for the differences can be given. If the public researchers were picking winners, the private deadweight would be estimated to be high, relative to public deadweight. On the other hand, if firms systematically exaggerated the importance of assistance, they would report a much lower deadweight compared to public assessment. These simple statistics do not, however, straightforwardly support either the pick-the-winners or response effect hypotheses. Instead, asymmetric information seems the more likely explanation. The researcher does not know the real deadweight and thus results more likely to the most indefinite option of partial deadweight. The significant correlation of two private assessments supports the reliability of private assessment. This dependence is fairly 
thin, which may indicate that the question of subsidy replacement possibilities is clearer and more concrete for the firms.

\section{Determination of deadweight}

The determination of deadweight for a particular project is investigated using econometric models. In all three cases, the determinant, project deadweight, is measured on an ordered, three-level scale ranging from 1 to 3 . This suggests the use of ordered probit models (see eg Long, 1997). ${ }^{13}$ In each case, it is assumed that $y_{i}$, the observed categorical level of deadweight of a project $i$, is determined according to a latent variable $y_{i}{ }^{*}$ :

$$
\begin{aligned}
& y_{i}^{*}=\beta^{\prime} x_{i}+\varepsilon_{i}, \quad \varepsilon_{i} \sim N(0,1) \\
& y_{i}=j \quad \text { if } \quad \kappa_{j-1}<y_{i}^{*} \leq \kappa_{j}, \quad j=1,2,3 \quad \text { (zero, partial, full) }
\end{aligned}
$$

where $x_{i}$ is a set of explanatory variables, $\beta$ is a parameter vector, and $\kappa \mathrm{s}$ are unknown threshold parameters $\left(\kappa_{0}=-\infty\right.$ and $\left.\kappa_{3}=\infty\right)$. The error term $\varepsilon_{i}$ is the distributed standard normal. ${ }^{14}$ Given these assumptions, the probability of deadweight level $j$ can be computed as

$$
\operatorname{Pr}\left(y_{i}=j\right)=\Phi\left(\kappa_{j}-\beta^{\prime} x_{i}\right)-\Phi\left(\kappa_{j-1}-\beta^{\prime} x_{i}\right),
$$

where $\Phi($.$) denotes the cumulative distribution function of the standard normal.$

The explanatory variables used in the model include firm-level and project-level factors, and the characteristics of the region where the firm is located. One limitation of most deadweight studies is that they focus only on one particular year, which is insufficient to

\footnotetext{
${ }^{13}$ The ordered characteristic in the dependent variables would not be reached, had we used, for example, multinomial logit (MNL) model. Another difficulty with the MNL model is that, although it is more flexible in terms of estimated parameters, it may be impossible to estimate the parameters for all classes if the number of observations in one class is small. In analysis of deadweight, for example, the number of firms reporting full deadweight can be small (see Table $1)$.
} 
illustrate any trend in the deadweight (McEldowney, 1997). Our data include observations from four consecutive years; hence, we are able to capture cyclical changes in the deadweight using three year dummies. The explanatory variables are described in more detail in the Appendix (Table A1).

Table 3 displays the estimation results of the ordered probit models for deadweight. The first column gives the determinants of deadweight based on the public assessment of deadweight (population data). The second column reports our estimates for the direct private assessment of deadweight, followed by the indirect assessment of deadweight based on the subsidy replacement possibilities as reported by firms (sample data). A variable with a positive (negative) coefficient is associated with an increased (decreased) deadweight. To allow for a comparison of the magnitude of the effects, marginal effects on the probability that deadweight is partial or full ${ }^{15}$ are given in Appendix (see Table A2).

\footnotetext{
${ }^{14}$ Due to normalization, only two threshold parameters, but no constant, are estimated.

${ }^{15}$ For brevity, only these marginal effects are reported instead of separate marginal effects for zero, partial and full deadweight. Note that the marginal effect on the probability of zero deadweight is the additive inverse of the marginal effect reported in Table A3.
} 
Table 3. Determination of deadweight: parameter estimates of ordered probit models

\begin{tabular}{|c|c|c|c|c|c|c|}
\hline \multirow{2}{*}{$\begin{array}{l}\text { Variable } \\
\text { Firm characteristics }\end{array}$} & \multicolumn{2}{|c|}{$\begin{array}{l}\text { 1a) Deadweight } \\
\text { assessment by } \\
\text { researchers }\end{array}$} & \multicolumn{2}{|c|}{$\begin{array}{l}\text { 2) Deadweight } \\
\text { assessment } \\
\text { by firms }\end{array}$} & \multicolumn{2}{|c|}{$\begin{array}{l}\text { 3) Subsidy } \\
\text { replacement } \\
\text { possibilities as } \\
\text { reported by firms }\end{array}$} \\
\hline & & & & & & \\
\hline New firm & $-0.226 * *$ & $(0.107)$ & -0.093 & $(0.699)$ & -0.415 & $(0.497)$ \\
\hline Employees & 0.001 & $(0.001)$ & $-0.014 *$ & $(0.008)$ & -0.012 & $(0.009)$ \\
\hline Turnover of firm & $0.033 * * *$ & $(0.010)$ & $0.243 * * *$ & $(0.084)$ & $0.238 * *$ & $(0.099)$ \\
\hline \multicolumn{7}{|l|}{ Project characteristics } \\
\hline Project costs & $-0.378 * * *$ & $(0.097)$ & 0.162 & $(0.299)$ & $-0.867 * * *$ & $(0.316)$ \\
\hline Project costs squared & $0.019 * *$ & $(0.009)$ & & & & \\
\hline Intensity of assistance & $-0.021 * * *$ & $(0.003)$ & $-0.059 * * *$ & $(0.018)$ & $-0.028 *$ & $(0.014)$ \\
\hline Investment project & $-0.416 * * *$ & $(0.109)$ & $-1.559 * * *$ & $(0.541)$ & -0.424 & $(0.487)$ \\
\hline Inv.proj. $\times$ new firm & $0.268 * *$ & $(0.129)$ & 0.388 & $(0.747)$ & 0.381 & $(0.609)$ \\
\hline Start-up project & -0.027 & $(0.115)$ & 0.678 & $(0.708)$ & 0.543 & $(0.502)$ \\
\hline \multicolumn{7}{|l|}{ Industry } \\
\hline Metal & $-0.185^{* * *}$ & $(0.069)$ & -0.317 & $(0.326)$ & -0.237 & $(0.275)$ \\
\hline Wood & $-0.265 * * *$ & $(0.080)$ & $-1.350 * * *$ & $(0.385)$ & -0.216 & $(0.316)$ \\
\hline Other manufacturing & $-0.183 * * *$ & $(0.067)$ & $-0.682 *$ & $(0.347)$ & -0.444 & $(0.283)$ \\
\hline Trade & -0.069 & $(0.096)$ & -0.197 & $(0.364)$ & -0.399 & $(0.447)$ \\
\hline Transport & -0.226 & $(0.142)$ & $-1.486^{* * *}$ & $(0.467)$ & $-0.951^{*}$ & $(0.548)$ \\
\hline Other industries & -0.034 & $(0.091)$ & -0.291 & $(0.420)$ & -0.647 & $(0.400)$ \\
\hline \multicolumn{7}{|l|}{ Regional characteristics } \\
\hline Unemployment rate $(\%)$ & $-0.016 * *$ & $(0.007)$ & 0.044 & $(0.031)$ & 0.005 & $(0.025)$ \\
\hline R\&D expenditure & $0.018 * * *$ & $(0.005)$ & 0.008 & $(0.022)$ & 0.030 & $(0.026)$ \\
\hline \multicolumn{7}{|l|}{ Year dummies } \\
\hline 2000 & $0.223 * * *$ & $(0.072)$ & 0.295 & $(0.382)$ & $0.734 * * *$ & $(0.277)$ \\
\hline 2001 & $0.182 * * *$ & $(0.065)$ & 0.267 & $(0.346)$ & 0.201 & $(0.279)$ \\
\hline 2002 & 0.080 & $(0.068)$ & 0.039 & $(0.347)$ & 0.181 & $(0.276)$ \\
\hline \multicolumn{7}{|l|}{ Threshold parameters } \\
\hline$\kappa_{1}$ & -2.068 & $(0.181)$ & -3.299 & $(0.794)$ & -1.409 & $(0.775)$ \\
\hline$\kappa_{2}$ & 1.356 & $(0.176)$ & -0.830 & $(0.756)$ & -0.384 & $(0.774)$ \\
\hline Log-likeliho & \multicolumn{2}{|c|}{-2396.08} & \multicolumn{2}{|c|}{-130.57} & \multicolumn{2}{|c|}{-190.90} \\
\hline No. of observations & \multicolumn{2}{|c|}{4932} & \multicolumn{2}{|c|}{187} & \multicolumn{2}{|c|}{188} \\
\hline
\end{tabular}

The literature on industrial policy suggests that a firm's access to finance increases with the size and business experience of the firm (eg Storey, 1994; Wren, 1998). Young firms do not have much evidence to show their competence and trustworthiness. Banks and other lenders may be too risk-averse or too unfamiliar with the new business to lend the money needed through early loss-making and risky years. Small firms may also face 
financial constraints, as they are unlikely to be monitored by rating agencies or the financial press. Hence, we would expect deadweight to increase with the size and business experience of the firm.

Our results are in accordance with these expectations. Deadweight increases significantly with turnover, regardless of the measure used, ceteris paribus. The magnitude of the impact is largest when the deadweight is asked indirectly from the firms. If the turnover increases by one million euro, the probability of deadweight (partial or full) increases by almost nine percentage points. The impact of turnover on deadweight is estimated to be smaller in the direct assessment of deadweight (marg. eff. $5.5 \%$ ), and particularly in the public assessment of deadweight (marg. eff. $0.8 \%$ ). The results based on public assessment of deadweight show that deadweight is smaller for new firms than for old firms, apart from those firms implementing investment projects. Directions of the effects are the same but coefficients are not significant when private measures of deadweight are used. However, contrary to Lenihan (2004), the size of the firm, in terms of number of employees, does not seem to be an important determinant of deadweight in any of the assessments.

Alongside the characteristics of the firm, we must pay attention to the characteristics of the project, as the project may have different risk attributes than the overall firm. The above discussion led us to suspect that larger costs imply greater project risk and smaller deadweight. Our results are consistent with these views. Apart from in very large projects (over $€ 10$ million), project costs have a negative effect on the deadweight in the public assessments. Project costs are included in squared form to capture the nonlinear effect on deadweight. The squared term was highly insignificant in the private assessments of deadweight, and was dropped therefore from the final specifications 
reported in columns 2 and $3 .{ }^{16}$ In the indirect assessment, the cost effect is large and negative. Contrary to our expectations, project costs do not, however, significantly affect deadweight in the direct private assessment (column 2).

Intensity of public assistance for the project has been calculated as a ratio of grant to total project costs $(\%)$. On one hand, high intensity of assistance may reflect the importance of assistance in the implementation of the project (small deadweight). For example, the project may be too costly relative to its returns for an individual firm, while having significant positive external effects on the local economy. On the other hand, high intensity of public assistance may also increase deadweight, as it tends to advance the chances of generating additional finance from the private sector. Our results suggest that the former effect dominates the latter. The intensity of assistance has a negative and significant impact on deadweight. The probability of deadweight decreases approximately by one percentage point when the intensity of assistance increases by one percentage point. In the public assessment of deadweight, the effect is again significant but only by half the magnitude.

The type of project is also a significant determinant of deadweight. The public assessment of deadweight implies that, for existing firms, investment projects have an about ten percentage point smaller probability of deadweight than development projects, ceteris paribus. Therefore deadweight seems to be a lesser problem in investment projects than in development projects. These differences may be related to project costs and the risks involved in the projects, or firms may simply rely more on public support when investment decisions are planned. Physical capital tends to be more difficult to move from one region to another than the outcome of a development project: a factor

\footnotetext{
${ }^{16}$ We also tried to add the investment-bearing capacity of the firm, defined as the ratio of turnover to project costs, to the models; but it was highly insignificant in all three models and
} 
that may increase risks in investment projects. The difference between the project types is estimated as smaller (4\%) for new firms, and greater when private assessment of deadweight is used.

Regarding industry effects, deadweight is estimated to be smallest in wood and transport industries when public and direct assessment of deadweight are used (cf. Tokila et al, 2008). Interestingly, the negative effects are particularly large and significant when direct private deadweight assessment is used. One partial possible explanation for these findings is that the wood and transportation industries are capitalintensive and have traditionally been supported by the state (see eg Junka, 1998). In indirect assessment, only the transportation industry shows significantly low levels of deadweight. This may indicate that in reality, deadweight is not dependent on the industrial sector, as subsidy replacement possibilities do not differ significantly between sectors.

Regional characteristics only reach statistical significance in public assessment of deadweight. Deadweight decreases with the unemployment rate in the region, and increases with $R \& D$ expenditures in the region. This may indicate that authorities tend to exaggerate the regional aspect of the subsidies, although in reality they do not influence the deadweight of the project. This public emphasis is, presumably, particularly strong when economic disparities are large, and public sector aims at reducing those disparities. Regional differences have increased after the deep recession in the early 1990s: a serious concern for regional development and policy; see, for example, the discussion in Tervo (2005) and in Kangasharju and Pekkala (2004). Note 
also a decreasing trend in deadweight between 2000 and 2003 (see year dummies in columns $1 \mathrm{a}$ and 3$).{ }^{17}$

In summary, public and private sectors emphasize different determinants in their assessment. Public assessment of deadweight seems best explained by the variables. ${ }^{18}$ The researchers clearly emphasize project costs, form of subsidy, industrial sector, and regional characteristics in their assessment, although no exact directions on how to define deadweight are given. The firms themselves make their assessment based on the size of the firm, form of subsidy, and industrial sector. Inestimable factors such as the riskiness of a project probably affect the firms' assessment more. The control measure of subsidy replacement possibilities is weakest as explained by the chosen composition of variables. The impact is dominated by the financial factors. These results suggest that deadweight measures are formed divergently. The difference between 2) and 3) is the most problematic. It indicates that the firms do not internalize direct and indirect deadweight similarly. These differences in determinants are likely to cause the differences in deadweight measures as well.

\section{Estimating deadweight spending}

Another way of looking at deadweight is to ask how much public money is spent on the non-additional projects. To arrive at an estimate of the deadweight spending, we will first add up the public assistance on the three types of subsidized projects (zero, partial, and pure deadweight). We let $S^{z}, S^{p}$, and $S^{f}$ denote public spending on all the zero,

\footnotetext{
${ }^{17}$ The number of subsidized projects decreased in 2000-2003, which may suggest that projects were more carefully selected during the latter part of the period, and explain the decreasing trend in deadweight. The profitability of SMEs remained good and largely unchanged during the period (Statistics Finland, 2004).

${ }^{18}$ Of course, this is partly due to the larger sample size.
} 
partial, and full deadweight projects respectively. ${ }^{19}$ The deadweight spending on a project is clearly zero if abandoned in the absence of subsidy (i.e. zero deadweight) ${ }^{20}$ Accordingly, if a project is implemented unchanged in the absence of subsidy (full deadweight), then the public assistance completely substitutes private funds (pure deadweight spending). Hence, the degree of deadweight spending (DWS, \%) can be estimated as a ratio of deadweight spending to the total public subsidies, as follows:

$$
D W S=100 \cdot\left(0 \cdot S^{z}+\theta \cdot S^{p}+1 \cdot S^{f}\right) /\left(S^{z}+S^{p}+S^{f}\right)
$$

where $S^{z}+S^{p}+S^{f}$ is the total public spending on subsidized projects, $0 \cdot S^{z}+\theta \cdot S^{p}+1 \cdot S^{f}$ is an estimate of the amount of public spending that substitutes private funds, and $\theta$ is the assumed degree of deadweight in the partial deadweight case $(0 \leq \theta \leq 1)$

Equation (4) can be used to estimate the range of deadweight spending by varying the parameter $\theta$. We obtain a lower bound for the estimate of the degree of deadweight spending by assuming that deadweight is zero at the partial deadweight category (i.e. setting $\theta=0$ ). By setting $\theta=1$, we obtain an upper bound for the estimate. Naturally, if we are willing to assume, for example, that $\theta=0.5$, we then obtain a "middle" estimate for the degree of deadweight spending from the middle of the two bounds. ${ }^{21}$ Note that these estimates will naturally depend on the operationalization of the deadweight concept (cf. Table 1).

\footnotetext{
${ }^{19}$ That is, $S^{z} \equiv \sum_{i} S_{i}^{z}$, where $S_{i}^{z}$ is the public assistance on a project $i$ with zero deadweight.

${ }^{20}$ Note, however, that the reverse is not necessarily true. If public assistance acts as an incentive ('leverage'), i.e. increasing private spending on a project (cf. Wren, 1996, page 535), and the project would have been implemented smaller but on a positive scale in the absence of subsidy, then the deadweight spending is zero, but the deadweight is nevertheless positive.

${ }^{21}$ The reasoning is that deadweight spending is a linear function of $\theta$. One way to arrive at $\theta=$ 0.5 is to consider $\theta$ as uniformly distributed between 0 and 1 across projects. Then the expected value of $\theta$ is 0.5 .
} 
Public subsidies and estimated deadweight spending are reported in Table $4,{ }^{22}$ and are given for each of our deadweight measures. Looking at the reported population figures first, we can see that almost $€ 205$ million of business subsidies were granted in 2000 2003. Most subsidies were spent on partial deadweight projects. However, it is reassuring to find that the amount of assistance is, on average, largest for the zero deadweight projects. Deadweight spending is estimated to be between 1.6 and $73.5 \%$.

Table 4. Public subsidies and deadweight spending

\begin{tabular}{|c|c|c|c|}
\hline $\begin{array}{l}\text { 1a) DW assessment } \\
\text { by researchers } \\
\text { (population) }\end{array}$ & $\begin{array}{c}\text { Public } \\
\text { subsidies, } \\
\text { on average }\end{array}$ & $\begin{array}{l}\text { Public } \\
\text { subsidies, } \\
\text { in total }\end{array}$ & $\begin{array}{c}\text { Estimated deadweight } \\
\text { spending }\end{array}$ \\
\hline Zero $(\mathrm{N}=967)$ & 56077.8 & 54227209 & If $\theta=0$, then $D W S=1.6 \%$ \\
\hline Partial $(\mathrm{N}=4695)$ & 31381.1 & 147334140 & If $\theta=0.5$, then $D W S=37.6 \%$ \\
\hline Full $(\mathrm{N}=82)$ & 40917.1 & 3355203 & If $\theta=1$, then $D W S=73.5 \%$ \\
\hline Total $(\mathrm{N}=5744)$ & 35674.9 & 204916552 & \\
\hline $\begin{array}{l}\text { 1b) DW assessment } \\
\text { by researchers } \\
\text { (sample) }\end{array}$ & $\begin{array}{c}\text { Public } \\
\text { subsidies, } \\
\text { on average }\end{array}$ & $\begin{array}{l}\text { Public } \\
\text { subsidies, } \\
\text { in total }\end{array}$ & $\begin{array}{l}\text { Estimated deadweight } \\
\text { spending }\end{array}$ \\
\hline Zero $(\mathrm{N}=36)$ & 81389.9 & 2930036 & If $\theta=0$, then $D W S=0.2 \%$ \\
\hline Partial $(\mathrm{N}=183)$ & 27840.7 & 5094852 & If $\theta=0.5$, then $D W S=31.9 \%$ \\
\hline Full $(\mathrm{N}=3)$ & 4326.7 & 12980 & If $\theta=1$, then $D W S=63.5 \%$ \\
\hline Total $(\mathrm{N}=222)$ & 36206.6 & 8037868 & \\
\hline $\begin{array}{l}\text { 2) DW assessment } \\
\text { by firms }\end{array}$ & $\begin{array}{c}\text { Public } \\
\text { subsidies, } \\
\text { on average }\end{array}$ & $\begin{array}{l}\text { Public } \\
\text { subsidies, } \\
\text { in total }\end{array}$ & $\begin{array}{l}\text { Estimated deadweight } \\
\text { spending }\end{array}$ \\
\hline Zero $(\mathrm{N}=47)$ & 44688.3 & 2100349 & If $\theta=0$, then $D W S=8.1 \%$ \\
\hline Partial (N = 149) & 35271.7 & 5255478 & If $\theta=0.5$, then $D W S=41.0 \%$ \\
\hline Full $(\mathrm{N}=25)$ & 26081.6 & 652041 & If $\theta=1$, then $D W S=73.8 \%$ \\
\hline Total $(\mathrm{N}=221)$ & 36234.7 & 8007868 & \\
\hline $\begin{array}{l}\text { 3) Subsidy } \\
\text { replacement } \\
\text { possibilities as } \\
\text { reported by firms }\end{array}$ & $\begin{array}{c}\text { Public } \\
\text { subsidies, } \\
\text { on average }\end{array}$ & $\begin{array}{l}\text { Public } \\
\text { subsidies, } \\
\text { in total }\end{array}$ & $\begin{array}{c}\text { Estimated deadweight } \\
\text { spending }\end{array}$ \\
\hline Zero $(\mathrm{N}=74)$ & 37698.8 & 2827411 & If $\theta=0$, then $D W S=25.4 \%$ \\
\hline Partial $(\mathrm{N}=79)$ & 40113.4 & 3168955 & If $\theta=0.5$, then $D W S=45.1 \%$ \\
\hline Full $(\mathrm{N}=68)$ & 30022.1 & 2041502 & If $\theta=1$, then $D W S=64.8 \%$ \\
\hline Total $(\mathrm{N}=222)$ & 36206.6 & 8037868 & \\
\hline $\begin{array}{ll}\text { Notes: } & \text { Deadweight } \\
& \text { where } S^{z}, S \\
& \text { and } \theta \text { is the }\end{array}$ & $\mathrm{g}$ is con & s $\quad D W S=1$ & $\begin{array}{l}\left.+1 \cdot S^{f}\right) /\left(S^{z}+S^{p}+S^{f}\right) \\
\text { full deadweight projects, }\end{array}$ \\
\hline
\end{tabular}

${ }^{22}$ We only consider deadweight spending on the subsidized firms. However, raising public funds for subsidies requires imposing taxes elsewhere in the economy, which in turn tends to create further deadweight loss in the market as discussed in the standard economic literature (see, for instance, Frank and Bernanke 2001). 
The sample data allow for better comparison of the deadweight, because the figures are based on the same projects. Deadweight spending is now estimated to be between 0.2 and $63.5 \%$; that is, when the deadweight measure is based on public assessment $(31.9 \%$ in the middle; assuming $\theta=0.5$ ). In direct private assessment, the upper bound estimate for the deadweight spending is larger (73.8\%); the lower bound estimate (8.1\%) and middle estimate $(41.0 \%)$ increase as well. Indirect assessment of deadweight, based on subsidy replacement possibilities, leads to the narrowest range of deadweight spending (25.4-64.8\%).

As deadweight spending is defined and estimated differently in previous studies, they cannot be directly compared to the estimates of this study. Foley (1992) reported that deadweight spending can be up to 90\%, whereas De Koning (1993) discovered deadweight spending as low as $40 \%$. Lenihan and Hart (2004) estimated a range of deadweight spending at $46.2-55.8 \%$. Our estimates show a larger range than in any of previous studies. Obviously, this results from the fact that no assumptions were made concerning partial deadweight. If we are willing to assume that, on average, $\theta$ is 0.5 in the case of partial deadweight, the results are in line with prior evidence.

\section{Conclusion}

Deadweight represents a situation in which public and private benefits diverge. Regardless, it must be assumed that only a firm knows the real deadweight, whereas a representative of the public sector attempts to elicit it using certain criteria. If these criteria (the subsidy program) are designed correctly, the deadweight measures of the public and private sectors should be similar. Previously, deadweight has been studied by public and private measures separately. The novelty of our paper has been the joint evaluation of the two measures of deadweight; namely, we have discussed and compared deadweight assessments by public sector and by private firm. Furthermore, 
we have used an alternative measure of subsidy replacement possibilities as a baseline for the reliability of direct measures.

First, we discovered some form of deadweight in $66-84 \%$ of the subsidized projects. The largest deadweight estimate was obtained from public assessment; this result does not support the pick-the-winners theory. Researchers do not seem to understate the possibility of deadweight, though this might result in less approved assistance. The control question yielded the smallest deadweight numbers, implying that firms' representatives do not intentionally underestimate when directly assessing deadweight.

Second, when considering the correlation between different measures of deadweight, no strong relation was found. Results did not show a significant relation between the public assessment of deadweight and the indirect measurement of private deadweight. The strongest correlation was found between the two private measures of deadweight. Thus private assessment may be closest to the real deadweight, as expected. Public and private assessments clearly constitute different measures for deadweight, and cannot be used as substitutes. However, no evidence was found either for the pick-the-winners effect or for the response bias. Instead, asymmetric information seems the more likely explanation for the differences. Public assessment may not be able to recognize the real deadweight of the project due to asymmetric information, as many essential features of the project and its funding possibilities are only known to the firm. As the researcher does not know the real deadweight, it can be tempting to select the most indefinite option, partial deadweight.

Third, the characteristics that affect deadweight measures were identified. Analysis supports the fact that the measures are divergently formed. The public and private sectors emphasize, in part, different aspects in their reviews, which may indicate that the subsidy program is not able to recognize the reasons that cause real deadweight. 
Therefore, they may not be able to pick those projects that need subsidies most severely. The control variable is explained by purely financial factors. The difference between direct and indirect private assessments may indicate that the question of deadweight is fully clear to the respondents. More evidence is needed to study this in detail.

Finally, our analysis showed that deadweight spending is a serious issue. By all measures, a significant share of subsidies is used potentially as deadweight spending, for reasons that should be more widely analyzed. Analysis demonstrated that without creating a set of additional assumptions (see, for example, Lenihan, 1999), the range of estimates for deadweight spending tends to be wide. In future, this issue of partial deadweight requires more thorough investigation.

All in all, this study shows that assessments from public and private views constitute different measures of deadweight. The measures should not be used as substitutes but rather as complements. When reporting deadweight, the source of the information should be highlighted, and policy recommendations drawn from the view of the source only. 


\section{Appendix}

Table A1. Definitions of variables and their mean values

\begin{tabular}{|c|c|c|}
\hline Variable & Definition & Mean \\
\hline \multicolumn{3}{|l|}{ Firm characteristics } \\
\hline New firm & $\begin{array}{l}1 \text { if the project is implemented by the new firm (definition by } \\
\text { Statistics Finland); } 0 \text { otherwise. }\end{array}$ & 0.218 \\
\hline Employees & The number of employees in the firm. & 16.069 \\
\hline Turnover of firm & Annual turnover of the firm ( $€$ millions). & 1.754 \\
\hline \multicolumn{3}{|c|}{ Project characteristics } \\
\hline Project costs & $\begin{array}{l}\text { Total project costs (i.e. purchasing cost of the fixed assets) as } \\
\text { estimated by the firm in its subsidy application ( } € \text { millions). }\end{array}$ & 0.149 \\
\hline $\begin{array}{l}\text { Intensity of } \\
\text { assistance }\end{array}$ & Ratio of the grant to the total project costs $(\%)$ & 32.182 \\
\hline Investment project & 1 if the project is an investment project; 0 otherwise. & 0.524 \\
\hline Start-up project & 1 if it is about starting-up a business; 0 otherwise. & 0.107 \\
\hline $\begin{array}{l}\text { Development } \\
\text { project }\end{array}$ & $\begin{array}{l}1 \text { if it is a development project (enhancing competitiveness or } \\
\text { internationalization of enterprise); } 0 \text { otherwise. (reference) }\end{array}$ & 0.369 \\
\hline \multicolumn{3}{|l|}{ Industry } \\
\hline Metal & $\begin{array}{l}1 \text { if the project is manufacturing of fabricated metal products; } \\
0 \text { otherwise. }\end{array}$ & 0.255 \\
\hline Wood & $\begin{array}{l}1 \text { if the project is manuf. of wood and of products of wood and } \\
\text { cork, incl. furniture, or of articles of straw and plaiting } \\
\text { materials; } 0 \text { otherwise. }\end{array}$ & 0.135 \\
\hline $\begin{array}{l}\text { Other } \\
\text { manufacturing }\end{array}$ & $\begin{array}{l}1 \text { if the project is in another manufacturing industry; } 0 \\
\text { otherwise. }\end{array}$ & 0.255 \\
\hline Trade & $\begin{array}{l}1 \text { if the project is in wholesale and retail trade, repair of motor } \\
\text { vehicles, motorcycles and personal and household goods, or } \\
\text { hotels and restaurants; } 0 \text { otherwise. }\end{array}$ & 0.060 \\
\hline Transport & $\begin{array}{l}1 \text { if the project is in transport, storage and communication, or } \\
\text { financial intermediation; } 0 \text { otherwise. }\end{array}$ & 0.020 \\
\hline Business & $\begin{array}{l}1 \text { if the project is in real estate, renting, and business } \\
\text { activities; } 0 \text { otherwise. (reference) }\end{array}$ & 0.201 \\
\hline Other industries & 1 if the project is in another industry; 0 otherwise. & 0.074 \\
\hline \multicolumn{3}{|c|}{ Regional characteristics } \\
\hline $\begin{array}{l}\text { Unemployment rate } \\
(\%)\end{array}$ & $\begin{array}{l}\text { Unemployment rate }(\%) \text { in the municipality where the firm is } \\
\text { located. Source: Statistics Finland. }\end{array}$ & 12.590 \\
\hline R\&D expenditures & $\begin{array}{l}\text { Research \& development expenditures ( } € 100 \text { million) in the } \\
\text { NUTS4 region where the firm is located. Source: Statistics } \\
\text { Finland. }\end{array}$ & 2.635 \\
\hline \multicolumn{3}{|l|}{ Year } \\
\hline 2000 & 1 if the funding was granted in $2000 ; 0$ otherwise. & 0.259 \\
\hline 2001 & 1 if the funding was granted in $2001 ; 0$ otherwise. & 0.366 \\
\hline 2002 & 1 if the funding was granted in $2002 ; 0$ otherwise. & 0.256 \\
\hline 2003 & 1 if the funding was granted in 2003; 0 otherwise. (reference) & 0.118 \\
\hline
\end{tabular}

Notes: Only the projects of private firms are included. Industry dummies have been created using the TOL 2002 industrial classification. Means have been computed using the estimation sample, where observations with missing information have been deleted (no. of obs. is 4 932). 
Table A2. Marginal effects on the probability of deadweight (partial or full)

\begin{tabular}{|c|c|c|c|c|c|c|}
\hline \multirow{2}{*}{$\begin{array}{l}\text { Variable } \\
\text { Firm characteristics }\end{array}$} & \multicolumn{2}{|c|}{$\begin{array}{l}\text { 1a) Deadweight } \\
\text { assessment by } \\
\text { researchers }\end{array}$} & \multicolumn{2}{|c|}{$\begin{array}{l}\text { 2) Deadweight } \\
\text { assessment } \\
\text { by firms }\end{array}$} & \multicolumn{2}{|c|}{$\begin{array}{l}\text { 3) Subsidy } \\
\text { replacement } \\
\text { possibilities as } \\
\text { reported by firms }\end{array}$} \\
\hline & & & & & & \\
\hline New firm & $-0.058 * *$ & $(0.029)$ & -0.021 & $(0.167)$ & -0.155 & $(0.191)$ \\
\hline Employees & 0.000 & $(0.000)$ & -0.003 & $(0.002)$ & -0.004 & $(0.003)$ \\
\hline Turnover of firm & $0.008 * * *$ & $(0.002)$ & $0.055^{* * *}$ & $(0.020)$ & $0.085 * *$ & $(0.035)$ \\
\hline \multicolumn{7}{|l|}{ Project characteristics } \\
\hline Project costs & $-0.091 * * *$ & $(0.023)$ & 0.037 & $(0.068)$ & $-0.311 * * *$ & $(0.112)$ \\
\hline Project costs squared & $0.005^{* *}$ & $(0.002)$ & & & & \\
\hline Intensity of assistance & $-0.005^{* * *}$ & $(0.001)$ & $-0.013 * * *$ & $(0.004)$ & $-0.010^{*}$ & $(0.005)$ \\
\hline Investment project & $-0.099 * * *$ & $(0.026)$ & $-0.276^{* * *}$ & $(0.085)$ & -0.146 & $(0.160)$ \\
\hline Inv. proj. $\times$ new firm & $0.058 * *$ & $(0.024)$ & 0.074 & $(0.118)$ & 0.125 & $(0.180)$ \\
\hline Start-up project & -0.007 & $(0.028)$ & 0.113 & $(0.085)$ & 0.172 & $(0.135)$ \\
\hline \multicolumn{7}{|l|}{ Industry } \\
\hline Metal & $-0.047 * *$ & $(0.018)$ & -0.078 & $(0.086)$ & -0.087 & $(0.103)$ \\
\hline Wood & $-0.070 * * *$ & $(0.023)$ & $-0.433 * * *$ & $(0.140)$ & -0.080 & $(0.120)$ \\
\hline Other manufacturing & $-0.046^{* * *}$ & $(0.018)$ & $-0.181^{*}$ & $(0.105)$ & -0.166 & $(0.108)$ \\
\hline Trade & -0.017 & $(0.025)$ & -0.048 & $(0.096)$ & -0.152 & $(0.177)$ \\
\hline Transport & -0.060 & $(0.042)$ & $-0.511 * * *$ & $(0.169)$ & $-0.365^{*}$ & $(0.197)$ \\
\hline Other industries & -0.008 & $(0.022)$ & -0.075 & $(0.121)$ & -0.250 & $(0.157)$ \\
\hline \multicolumn{7}{|l|}{ Regional characteristics } \\
\hline Unemployment rate $(\%)$ & $-0.004 * *$ & $(0.002)$ & 0.010 & $(0.007)$ & 0.002 & $(0.009)$ \\
\hline $\mathrm{R} \& \mathrm{D}$ expenditure & $0.004 * * *$ & $(0.001)$ & 0.002 & $(0.005)$ & 0.011 & $(0.009)$ \\
\hline \multicolumn{7}{|l|}{ Year dummies } \\
\hline 2000 & $0.051 * * *$ & $(0.016)$ & 0.061 & $(0.074)$ & $0.235^{* * *}$ & $(0.079)$ \\
\hline 2001 & $0.043^{* * *}$ & $(0.015)$ & 0.058 & $(0.072)$ & 0.071 & $(0.097)$ \\
\hline 2002 & 0.019 & $(0.016)$ & 0.009 & $(0.077)$ & 0.064 & $(0.095)$ \\
\hline Average predic & \multicolumn{2}{|c|}{0.843} & \multicolumn{2}{|c|}{0.857} & \multicolumn{2}{|c|}{0.676} \\
\hline No. of observations & \multicolumn{2}{|c|}{4932} & \multicolumn{2}{|c|}{187} & \multicolumn{2}{|c|}{188} \\
\hline \multicolumn{7}{|c|}{$\begin{array}{ll}\text { Notes: } & \text { First, the estimated marginal effect is given, followed by the robust standard error in brackets. } \\
& \text { Definitions of variables are given in Table A1. The marginal effects and the average predicted } \\
& \text { probabilities have been computed as the means of the independent variables, and using estimated } \\
& \text { parameters reported in Table } 3 . *(* *, * * *)=\text { Statistically significant at the } 0.10(0.05,0.01) \\
& \text { level. }\end{array}$} \\
\hline
\end{tabular}




\section{References}

Agresti A, 1984 Analysis of Ordinal Categorical Data (Wiley, New York)

Aid to Business Act, 1068/2000, in Ministry of Justice, 2006, Finnish Law I

Bartik T J, 1990, "The market failure approach to regional economic development policy” Economic Development Quarterly 4 361-370

Curran J, Storey D J, 2000, "Small Business Policy: Past Experiences and Future Directions", The Small Business Service and Kingston University Small Business Research Centre SME Seminar Series: Linking Research and Policy, DTI Conference Centre, 12th December, London, http://business.kingston.ac.uk/ research/kbssbs/currstor.pdf

Czarnitzki D, Fier A, 2002, "Do innovation subsidies crowd out private investment? Evidence from the German service sector" Applied Economics Quarterly 48 1-25

Davenport S, Grimes C, Davies J, 1998, "Research collaboration and behavioural additionality: a New Zealand case study" Technology Analysis \& Strategic Management 10 55-67

David P, Hall B, Toole A, 2000, "Is public R\&D a complement or substitute for private R\&D: a review of the econometric evidence" Research Policy 29 497-529

De Koning J, 1993, "Measuring the placement effects of two wage-subsidy schemes for the long-term unemployed" Empirical Economics 18 447-468

Decree of Council of State, 1200/2000, in Ministry of Justice, 2000, The Statutes of Finland

European Commission, 2003/361/EC, The Annex of Recommendation 2003/361/EC

European Commission, 2006, Evaluation Methods for the European Union's external assistance, Evaluation Tools, Volume 4, Luxemburg: Office for Official Publications of the European Communities

European Commission, 2007, Evaluation of data and sources underlying the analysis of market gaps in access to finance for SMEs in the EU, DG Enterprise and Industry, Luxemburg

Foley P, 1992, "Local economic policy and job creation: a review of evaluation studies" Urban Studies 29(3/4) 557-598

Frank R, Bernanke B, 2001 Principles of Microeconomics (McGraw-Hill, New York)

Georghiou L, Rigby J, Cameron H Eds, 2002, Assessing the Socio-economic Impacts of the Framework Programme, PREST Publications

Glancey K S, 2000 Entrepreneurial Economics (Palgrave, New York) 
González X, Jaumandreu J, Pázo C, 2005, "Barriers to innovation and subsidy effectiveness" Rand Journal of Economics 36 930-950

Heijs J, 2003, "Freerider behaviour and the public finance of R\&D activities in enterprises: the case of the Spanish low interest credits for R\&D” Research Policy $32445-461$

Hines Jr. J R, 1999, "Three sides of Harberger triangles" Journal of Economic Perspectives 13(2) 167-188

Junka T, 1998, Trends in the public support to industries in 1984-1996, in Finnish, Government Institute for Economic Research, Discussion Paper No. 165

Kaiser U, 2004, "Private R\&D and public subsidies: microeconometric evidence from Denmark", CEBR Discussion paper 2004-19, Denmark, www.cebr.dk/upload/dp2004-19.pdf

Kangasharju A, Pekkala S, 2004, "Increasing regional disparities in the 1990s: the Finnish experience", Regional Studies 38(3) 255-267

Kendall M G, Gibbons J D, 1990 Rank Correlation Methods $5^{\text {th }}$ ed (Oxford University Press, Oxford)

Lach S, 2002, "Do R\&D subsidies stimulate or displace private R\&D? Evidence from Israel" The Journal of Industrial Economics 4 369-390

Leach J, 2003, Course in Public Economics West Nyack (Cambridge University Press, New York)

Lenihan H, 1999, "An evaluation of a regional development agency's grants in terms of deadweight and displacement" Environment and Planning C: Government and Policy 17 303-318

Lenihan H, 2004, "Evaluating Irish industrial policy in terms of deadweight and displacement: a quantitative methodological approach” Applied Economics 36 229_ 252

Lenihan H, Hart M, 2004, "The use of counterfactual scenarios as a means to assess policy deadweight: an Irish case study" Environment and Planning C: Government and Policy 22 817-839

Lenihan H, Hart M, Roper S, 2005, "Developing an evaluative framework for industrial policy in Ireland: fulfilling the audit trail or an aid to policy development", in Economic and Social Research Institute, Quarterly Economic Commentary Summer 2005 pp. 69-85

Long J S, 1997 Regression Models for Categorical and Limited Dependent Variables (Sage, Thousand Oaks, CA) 
Luukkonen T, 2000, “Additionality of EU framework programs” Research Policy 29 $711-724$

McEldowney J J, 1997, "Policy evaluation and the concepts of deadweight and additionality" Evaluation 3(2) 175-188

Ministry of Trade and Industry, 2004, Annual Report 2003, Annual Reports of Ministry of Trade and Industry

Mueller D C, 2003 Public Choice III (Cambridge University Press, West Nyack, NY)

Muotio M, 1998, Pk-yritykset ja julkinen tuki, SMEs and the public support, in Finnish, Publications of Research Institute of University of Vaasa No 77, Vaasa

Parker S C, 2004 The Economics of Self-Employment and Entrepreneurship (Cambridge University Press, Cambridge)

Robinson F, Wren C, Goddard J, 1987 Economic Development Policies: An Evaluative Study of Newcastle Metropolitan Region (Clarendon Press, Oxford)

Stam E, Suddle K, Hessels S J A, van Stel A, 2007 High Growth Entrepreneurs, Public Policies and Economic Growth, Jena Economic Research Paper 2007-019, Jena, http://ssrn.com/abstract=1019429

Statistics Finland, 2004, Business enterprises - net results and balance sheets 2002, in Finnish, Helsinki

Stiglitz J E, 1988 Economics of the Public Sector $1^{\text {st }}$ ed (Norton, London)

Stiglitz J E, Weiss A, 1981, "Credit rationing in markets with imperfect information" American Economic Review 71 393-410

Storey D J, 1994 Understanding the Small Business Sector (Routledge, London)

Tervo H, 1989, "A micro-level approach to the analysis of the displacement effects of regional incentive policy: the case of Finland" Regional Studies 23 511-521

Tervo H, 1990, "Factors underlying displacement: an analysis of Finnish regional incentive policy using survey data on assisted firms" Applied Economics 22 617628

Tervo H, 2005, "Regional policy lessons from Finland" in Felsenstein D, Portnov B A Eds Regional Disparities in Small Countries (Springer, Berlin) pp. 267-282

Tokila A, Haapanen M, Ritsilä J, 2008, "Evaluation of investment subsidies - When is deadweight zero?" Forthcoming in International Review of Applied Economics

Venetoklis T, 2001, Business Subsidies and Bureaucratic Behaviour. A Revised Approach, VATT-Research Reports 83, Government Institute for Economic Research 
Wallsten S J, 2000, "The effects of government-industry R\&D programs on private R\&D: the case of the small business innovation research program" The Rand Journal of Economics 31(1) 82-100

Wren C, 1996, "Fund substitution and the incentive effects of public investment subsidies" Scottish Journal of Political Economy 43 534-548

Wren C, 1998, “Subsidies for job creation: Is small best?” Small Business Economics 10 273-281

Zimmermann H, 1985, "Der Mitnahmeeffekt. Inhalt und Meßkonzepte, dargestellt am Beispiel der Zuweisungen and Gemeinden“ in Räumliche Aspekte des Kommunalen Finanzausgleichs, Forschungs- und Sitzungsberichte der Akademie für Raumforschung und Landesplanung, Vol. 159, Hannover, pp. 293-311 